\title{
Anàlisi pragmaestilística de columnes periodístiques: aplicacions a l'ensenyament secundari
}

Sergi Serra Adsuara serraadsuara@gmail.com 
I. Resum

Dins de l'àmbit de l'ensenyament mitjà, la manera de plantejar els comentaris de text ha estat motiu de constants reflexions des de diferents perspectives teòriques. En aquest treball proposem exposar com la pragmaestilística esdevé una metodologia profitosa a fi d'assolir els objectius d'anàlisi textual en aquest nivell educatiu -especialment en batxillerat.

Amb aquesta intenció, hem descrit, a tall d'exemple, un ventall d'elements lingüístics i discursius des de la perspectiva pragmaestilística i, posteriorment, hem aplicat aquesta línia d'anàlisi a un corpus de columnes periodístiques atès que les característiques $d$ 'aquest gènere resulten una bona pedra de toc per a comprovar la validesa d'aquesta hipòtesi de treball.

En concret, en aquest article presentem una síntesi de la tasca que estem realitzant i, com a mostra, hi incloem un exemple de comentari de columna periodística que s'allunya de la rigidesa de les típiques plantilles d'anàlisi. En aquest aspecte la nostra intenció és palesar que cada text assenyala, a partir de les seues coordenades discursives, un mapa de comentari específic i, consegüentment, l'anàlisi interpretatiu que s'efectue ha de reflectir quins són els components estilístics que hi predominen i quines funcions pragmàtiques hi activen. A banda de la possibilitat de realitzar comentaris complets, no cal oblidar que podem emprar determinades columnes per explicar als alumnes com operen algunes tries lingüístiques dins d'un text.

Paraules clau: pragmaestilística, columna periodística, batxillerat, anàlisi textual, tries estilístiques i funcions pragmàtiques.

\section{Introducció}

Amb aquest treball, pretenem oferir una proposta de comentari que permeta tractar elements d'anàlisi textual des d'una perspectiva pragmaestilística des de la qual ajudar els alumnes a donar sentit als discursos d'una manera autònoma i crítica. Per a dur a terme aquesta tasca, hem optat per centrar el treball en un gènere -de què s'ha parlat $i$ escrit força-com és la columna escrita de premsa. De fet, entenem que la columna d'opinió, pel seu essencial hibridisme, és una bona pedra de toc per a apropar els alumnes a tot un mener de continguts discursius, pragmàtics $i$ estilístics que garantesquen aquest objectiu d'engegar el procés d'interpretació dels diferents components textuals a fi de poder copsar les intencions de l'autor.

Fet i fet, el gènere columna ens permet tractar, per una banda, aquells aspectes discursius que conviden a un tipus de contracte comunicatiu 
entre capçalera i autor i lector i, per una altra, analitzar els elements estilístics que endega l'autor amb la intenció d'exposar -o d'imposar- la seua visió dels mons de què escriu. Malgrat els esfumats límits del gènere, entenem que cal donar a l'alumnat les eines necessàries perquè conega l'articulat del contracte discursiu que el columnista -des del seu ethos- hi subscriu. D'aquesta manera, el lector acararà amb més seguretat els viaranys de l'acord comunicatiu i, tot compte fet, optarà per acceptar-lo o bé per rebutjar-lo des de la reflexió i l'esperit crític.

En un altre apartat, justifiquem com la perspectiva pragmaestilística resulta apta per a desenvolupar les anàlisis textuals atès que permet, per una banda, valorar els aspectes enunciatius que ara esmentàvem i, per una altra, analitza les funcions comunicatives dels components lingüístics -tot superant-ne la identificació superficial- a fi de reflexionar sobre les intencions comunicatives de la tria dels elements lingüístics i els efectes que aquestes tries estilístiques tenen sobre els destinataris.

Des d'aquesta proposta, en un apartat posterior i sense pretensions d'exhaustivitat, descrivim un ventall d'elements per aplicar aquests coneixements al comentari concret de les columnes. En aquest sentit, cal avançar que hem evitat apropar-nos als textos a partir d'una plantilla tancada d'anàlisi que acaba per convertir-se, manta volta, en una finalitat en si mateixa més que en un mitjà per analitzar obertament el text.

Paral-lelament, un altre factor consisteix a identificar quins components lingüístics resulten més opacs i copsar si cal esmerçar esforços a fi de superar la pura identificació morfosintàctica dels elements lingüístics, i altrament, atendre a les funcions pragmaticodiscursives que aquests elements engeguen en l'intercanvi comunicatiu.

En l'última part del treball presentem un exemple de comentari desenvolupat d'una columna periodística a partir de la qual aplicar aquesta visió de l'anàlisi textual, tot atenent a una sèrie d'objectius que ens semblen bàsics a l'hora d'acarar aquest contingut curricular.

Presentat aquest marc, les nostres hipòtesis de treball es concreten en aquests dos eixos:

- La pregona utilitat per a l'ensenyament de la llengua i la literatura del gènere columna ateses les seues característiques, entre les quals cal destacar la formalització elaborada i la brevetat.

- El fet d'aplicar una metodologia de comentari basada en la pragmaestilística permet defugir els habituals esquematismes d'aplicació automàtica i, altrament, practicar una flexibilitat en l'anàlisi que aconsegueix un diàleg individualitzat i contextualitzat entre allò que cada text ofereix i els lectors-alumnes. 
III. La columna periodística: evolució i característiques

Des dels orígens del periodisme, allà pel segle XVII, fins a l'actualitat el concepte de periodisme ha variat d'una manera pregona. Un dels canvis més destacats ha estat la multiplicitat de gèneres discursius que, des de les últimes dècades ençà, trobem dins de la premsa escrita.

Aquesta diversitat es palesa també dins dels anomenats subgèneres d'opinió, que també han matisat els seus trets en els darrers anys. Cal dir que un factor destacat per a distingir-los rau en la identitat del comentarista: aquell que medita sobre quelcom. Així, l'autor de l'editorial és el mateix periòdic, un lector concret ho és de la carta al director, un collaborador extern signa articles anomenats d'opinió i, respecte al gènere que ens ocupa, rep el nom de columnista aquell escriptor que publica periòdicament en una secció fixa i reservada per al seu text.

Si férem una revisió succinta dels orígens de la premsa i les seues manifestacions en països concrets, observaríem que, si bé a l'Anglaterra del XVIII fa via un estil que poua de l'assaig i que al segle $x x$ ha estat conreat com a gènere periodístic independent, serà en la premsa americana més moderna, per exemple amb personalitats com Walter Lippmann i la seua columna Today and Tomorrow, quan la columna trau el cap amb força a causa de la necessitat de diferenciar explícitament la veu editorial del periòdic de la signatura d'un autor concret al qual segueixen un nombre considerable de lectors. De fet, l'origen nordamericà de la columna moderna, tal i com la coneixem avui en dia, sorgeix durant les darreres dècades del segle passat per la necessitat de compensar amb una veu personal l'ocultació que pateix el jo del director $\mathrm{i}$ propietari quan el periòdic passa a estar regit ja no per un individu amb les seues dèries personals sinó per un grup editorial que traspua més fredor i distanciament (López Pan, 2008: 58).

Per aquesta raó primigènia la columna per a LI. Gomis és «un art i una tècnica que s'adapta a la personalitat del titular, com a periodisme personal que és» (Gomis, 1989: 167). Aquesta potència personal de l'autor fa que als EEUU hi haja columnistes que hi conreen àmbits específics: actualitat, esports, tafaneries, societat o humor. Un bon exemple, malgrat que ben antic, són les colyum humorístiques del corrosiu Ambrose Bierce (1842-1914).

A més a més, l'empremta personal fa que la columna tinga una flaire de certa intimitat o bé de confiança entre l'escriptor i el seu lector model. Aquest fet suposa una evident distinció respecte a la resta de subgèneres d'opinió. Així s'estableix aqueix pacte de lectura entre les temàtiques i l'estil habituals del columnista i el lector, que necessita conèixer qui li escriu i a qui espera llegir periòdicament. 
En aquest sentit podríem dir que l'autor basteix, amb cada columna, un ethos i, paral-lelament, l'horitzó d'expectatives del lector confia que el seu autor model regresse amb cada nova publicació, amb cada nova lectura. Tot i que sovint la columna es defineix a partir de factors paratextuals com la ubicació en un espai fix, els elements destacats tipogràficament, la periodicitat entre diària i setmanal, la signatura de l'autor, la brevetat o el fet d'anar encapçalada per un títol que dóna lloc a l'espai-columna; l'empremta de l'ethos del columnista és una variable clau en tota possible definició de columna. Així la defineix López Pan:

Texto periodístico de autoria unitaria que puede presentar diversas formas expresivas -narrativa, representativa o argumentativa- y temas, cuyo elemento configurador básico es el ethos del autor expresado a través de unos elementos formales que le permiten manifestarse con continuidad, lugar fijo y asiduidad (López Pan, 2008: 61-62).

En efecte, des de fa un bon grapat d'anys, les empreses periodístiques han apostat fort per contractar personalitats intel-lectuals i literàries a fi de fidelitzar sectors dels lectors/clients (Quim Monzó, Sergi Pàmies, Enric Sòria, Joan Francesc Mira, Manuel Vicent, Juan José Millás, Sánchez Ferlosio ...). Aquesta aposta pels columnistes de referència té relació directa amb la immediatesa amb què arriben actualment les notícies al ciutadà. Les noves tecnologies possibiliten accedir a les notícies en temps pràcticament real o, dit d'una altra manera, de forma quasi simultània als fets que succeeixen en aquest món globalitzat i líquid. Per tant, la premsa impresa tradicional pateix un període d'adaptació a causa de la funció que exerceixen aquests nous suports d'informació com ara les xarxes socials o la premsa digital i, per a mantindre la seua quota de mercat, sap que el seu únic esquer no pot ser la notícia d'actualitat clàssica vist que molts lectors ja la poden considerar desfasada en veure-la publicada al sendemà a la portada del periòdic.

Fet $\mathrm{i}$ fet, el periòdic i en bona mesura també els setmanaris han de reorientar el criteri de selecció de les notícies que publiquen $\mathrm{i}$, sobretot, fer d'aquells gèneres que no es caracteritzen essencialment per la variable de la immediatesa la senya d'identitat de la capçalera. Ras i curt, l'objectiu s'està desplaçant des dels els gèneres que informen dels fets envers aquells que ajuden el lector a contextualitzar-los i reflexionar-hi. Òbviament entre aquests es troba la columna, en molts casos com a gènere estrella de la publicació gràcies a l'autor que la signa. Vet ací que, des d'un punt de vista diacrònic, podem estar vivint un moment de capgirament pel que fa a l'essència del periodisme: si, com hem vist adés, la premsa fundacional se sustentava en la informació de fets, ara sembla tombar-se envers els comentaris de les opinions.

El fet de recórrer a escriptors, diguem-ne, de caràcter literari perquè es facen càrrec de les columnes d'opinió de determinades publicacions i hi aporten un grau de distinció i originalitat, determina que aquest gènere 
tinga unes particularitats pragmaticodiscursives ben destacades. Justament, aquest treball té la intenció d'identificar quins són els recursos pragmaestilístics que hi sovintegen i, posteriorment, proposar-ne estratègies d'aplicació a l'ensenyament mitjà. A aquestes peculiaritats hem d'afegir que la columna resulta, per la seua extensió reduïda, un text ben adient per a realitzar el tipus de lectura intensiva, analítica i crítica que requereix un cometari de text ja que garanteix «la unitat de percepció de l'objecte d'anàlisi i la possibilitat d'abastar-lo visualment com a conjunt, d'un sol cop d'ull» (Salvador, 2011: 119).

Per portar a terme aquest objectiu, en els apartats següents pretenem, en primer lloc, justificar el perquè de la pragmaestilística com a mètode de treball i, posteriorment, caracteritzar un grapat d'elements (lingüístics i extralingüístics) que des d'aquesta visió tenen una funció significativa en el context sociomediàtic en què operen les columnes d'opinió.

\section{Les potencialitats de la pragmaestilística}

Si en qualsevol expressió lingüística el context d'enunciació conté uns valors que permeten atorgar un significat adequat a allò expressat, en el cas dels escrits periodístics la importància dels factors d'enunciació sembla cabdal. De fet, aquests abeuren d'un context estretament lligat al moment de redacció i publicació.

Tot i que el caràcter efímer de les columnes d'opinió, per la idiosincràsia del gènere, és menor que el d'altres gèneres periodístics, hi ha factors extralingüístics que s'escapoleixen de la immanència del text i, per tant, superen l'abast explicatiu de les perspectives de la gramàtica o l'estilística tradicionals. Tot plegat fa que l'enfocament pragmàtic resulte òptim per estudiar, en el nostre cas, el gènere columna atès que ens permet conjuminar-hi els aspectes purament lingüístics de la gramàtica o de la lingüística textual amb els factors extralingüístics. Així, la perspectiva pragmaestilística encabeix diferents tipus d'elements de l'enunciació com ara l'emissor, el destinatari, l'enunciat, l'entorn, el context cognitiu compartit entre emissor i destinatari, les relacions socials, els objectius de l'autor, etc.

Tot ben garbellat, parlem de la visió pragmàtica que aposta per copsar els elements lingüístics amb la intenció d'analitzar no només què diu un enunciat sinó què fem quan l'expressem. Aquesta idea ens apropa a la teoria dels actes de parla de L. Austin i R. Searle quan exposen que les idees expressades no serveixen només per descriure o constatar realitats sinó que actuen com a enunciats realitzatius. En aquest sentit, ens sembla interessant observar quina presència tenen en les columnes d'opinió i quin paper hi juguen, per exemple, els actes il/locutius indirectes. 
Seguint amb la línia d'estudis que fan progressar la perspectiva pragmàtica i a partir de la teoria de la cooperació i del concepte d'implicatura de H. P. Grice, sorgeix la teoria de la pertinència. D. Sperber i D. Wilson proposen un mecanisme deductiu basat en el concepte de pertinència, segons el qual qui comunica una idea la vehicula amb un grau d'ostensió que permet al destinatari inferir, amb l'ajut del context, allò que l'emissor volia comunicar-hi. Tot plegat amb la menor despesa deductiva per part del destinatari.

En relació amb les columnes d'opinió, podrem observar en les anàlisis posteriors com, en alguns dels textos triats, els autors opten per encetarlos amb una mena d'esquer temàtic d'actualitat que resulte rellevant per als lectors per capgirar-ne la temàtica, tot seguit, una vegada que el lector ha mossegat l'ham de la pertinència.

A més a més, aquest feix de perspectives teòriques permet explicar el fort Iligam comunicatiu -i d'alguna manera afectiu- forjat entre columnista i lector model atès que el procés de dotar de sentit adequat als actes il-locutius indirectes, a la transgressió de les màximes conversacionals o a les implicatures esdevé més eficient quan ambdós sovintegen un espai comunicatiu i uns marcs cognitius comuns.

Si en aquest punt hem parlat de pragmàtica, caldrà ara fer esment de l'estilística, l'altre formant del concepte metodològic proposat. L'estilística té els seus orígens en l'elocutio de la retòrica clàssica, tot agafant volada gràcies a l'impuls del discurs escrit i, segles més tard, als estudis lingüístics que tindran com a fita màxima l'oració. Aquests paràmetres potenciaran l'estudi de l'estil davant d'altres components de la retòrica (inventio i dispositio). Aquestes premisses feren que l'estilística tractara de les microestructures lingüístiques i, especialment, de les figures retòriques del discurs literari escrit (Salvador, 2003: 2-3).

Tanmateix, les possibilitats de tria entre les diferents variants que la llengua ofereix en un context enunciatiu i lingüístic determinat no es limiten, ni de bon tros, al discurs literari sinó que aquesta potencialitat electiva opera en qualsevol situació comunicativa. Evidentment, també en l'àmbit dels gèneres periodístics $i$, en concret, en un gènere com la columna d'opinió que, pel cap alt, assenyala una determinada distribució de papers comunicatius en la interacció comunicativa entre autor i lector i, pel cap baix, explica l'elecció d'un registre funcional segons la tria d'uns específics elements lexicogramaticals que hi desenvolupen unes funcions determinades.

Si seguim el model clàssic de Buhler en què distingeix una triple funció del llenguatge, podrem observar com tant els símptomes, els senyals i els símbols es relacionen amb fenòmens vinculats a l'estudi de l'estil ja que, respectivament, tracten els signes segons remeten a l'autor, a l'efecte en el receptor o bé al referent extern designat pel signe. Així, tot i que els 
símptomes remetrien al subjecte del discurs i a les característiques que indicarien una autoria, també remeten a la tria efectuada davant d'un marc d'opcions possibles. En el cas dels senyals, si bé la funció de senyal és hereva dels efectes persuasius de la retòrica clàssica, l'estil imposa, diríem que intrínsecament, una perspectiva al destinatari. Finalment, la relació entre estil i la funció dels símbols lliga amb el contingut semàntic del discurs. En aquest apartat es pot destacar la importància d'entendre les relacions sinonímiques des d'una perspectiva pragmalingüística que palesa com determinades expressions considerades sinònimes poden mirar-se com a diferents si es tenen en compte aspectes pragmàtics (actes de parla indirectes o factors de cortesia) o la incorporació de biaixos axiològics a les unitats lèxiques (Salvador, 2003: 4-5).

Certament, aquest ventall d'enfocaments que convergeixen en la pragmaestilística ens permetrà analitzar aquests escrits periodístics eixamplant els models d'anàlisi que, sobretot des del punt de vista de l'ensenyament, se solen centrar en la lingüística textual. Al capdavall, el component pragmàtic afig a l'anàlisi estilística -que observava el text com una unitat aillada- una visió més rica en estudiar quines funcions desenvolupen els elements lingüístics triats dins d'un gènere, ací la columna, que estableix unes convencions discursives dins de l'àmbit periodístic.

\section{Descripció d'alguns components discursius}

Certament, no és aquest el tipus de treball que ens permeta fer una descripció extensa i matisada d'un nombre representatiu dels components discursius que poden tindre pertinència dins del gènere columna. Per açò, només volem fer ara cinc cèntims d'únicament tres components per tal que servesquen de mostra de l'orientació teòrica escollida.

\section{a) Ethos i pathos}

Si parlem dels efectes il-locutius i perlocutius de les columnes d'opinió, caldrà comentar els conceptes d'ethos i pathos com a mecanismes referits a l'enunciador $i$ als efectes sobre el destinatari. De fet, com dèiem adés en caracteritzar la columna, el concepte d'ethos resulta crucial per a especificar-la.

Certament, si tot gènere suposa per convenció un contracte entre els interlocutors, podríem dir que la columna té unes clàusules contractuals ben específiques ja que la figura del columnista, la seua signatura, el seu estil a l'hora de procedir amb els temes escollits -la tria del tema ja és un indicador de modalització- és cabdal per a entendre la relació amb el lector. Vet ací que entra en joc el concepte d'ethos entès, des de l'anàlisi del discurs vinculat al gènere, com la imatge o el rol que l'enunciador 
transmet als interlocutors. Alhora l'ethos també opera prèviament atès que l'auditori ha confeccionat una imatge d'aquest enunciador. Ara bé: dependrà del propi autor intentar refermar, matisar o modificar aquesta màscara.

De fet, pot ocórrer que els autors caiguen en la caricatura quan, en les seus produccions, radicalitzen aquell ethos que els lectors models esperen, de forma que malden per provocar els efectes que se'n esperen i, malauradament, la qualitat d'allò ofert al públic es redueix.

En relació directa amb la posada en escena discursiva d'aquesta màscara de la representació, tenim el pathos que, en retòrica, remet a un tipus d'argument que arrossega la voluntat des d'unes estratègies emotives per a aconseguir convèncer l'interlocutor.

De més a més, cal tindre en compte que la coherència del text $s^{\prime}$ ha d'entendre, des de enfocaments cognitius, com un procés en què els destinataris tenen un paper actiu a l'hora de donar significat als elements lingüístics i a la ubicació contextual del text en el cas dels gèneres periodístics. A partir d'aquestes premisses, el destinatari podrà interpretar allò implícit (implicatures i pressuposicions) sempre que compartesca amb l'ethos uns marcs i esquemes comuns; dit d'una altra manera, l'autor haurà d'haver activat un procés d'adaptabilitat del text als possibles lectors. Aquestes consideracions sobre els processos d'interpretació caldrà tindre-les ben presents en el moment de desplaçar les columnes d'opinió del context comunicatiu real (periòdic/lector) a la lectura a l'aula (classe/alumne). El professor haurà d'emplenar les dades que aquest lector desplaçat no pot inferir per culpa del canvi de context enunciatiu de l'escrit.

Ben mirat, aquestes reflexions ens condueixen a proposar un ethos del lector si entenem que aquest actua com un coenunciador inserit al propi text. Per tant, cada gènere en general $i$ cada text en particular elaboren una mena d'imatge d'aquest lector en assignar-li unes característiques específiques que haurà d'acomplir per reeixir en l'aspiració de significar profitosament l'obra (Maingueneau i Salvador, 1995:81-82).

Consegüentment, aquests conceptes al-ludeixen a les persones del discurs i, per tant, caldrà que ens referim sintèticament a alguns conceptes que es relacionen amb la presència dels subjectes en el text.

b) Elements díctics

Atenent a les característiques de la columna d'opinió, sembla obvi que podrem trobar la presència del subjecte enunciador en diferents elements textuals. Per una banda, tenim els díctics o marques lingüístiques que assenyalen elements del context comunicatiu. Existeixen tres classes de marques díctiques segons facen referència als interlocutors, l'espai o el temps de l'enunciació. La peculiaritat d'aquestes 
formes lingüístiques respecte als elements no díctics consisteix en el fet que prenen el significat del context concret en què es produeix l'acte comunicatiu. Per tant, el seu significat (jo, ara, ací) no és lèxic sinó gramatical i pragmàtic.

Les marques díctiques d'espai són els demostratius espacials (determinants, proformes i pronoms neutres) i els adverbis i locucions adverbials mentre que els díctics de temps són adverbis temporals, sintagmes nominals amb demostratius i morfemes verbals (Conca i altres, 1998: 34-36). Tot i que en els gèneres informatius hi ha una escissió entre el context de redacció i el context de recepció, que es manifesta explícitament en l'ús ortodox d'uns díctics que ubiquen els fets relatats en el context exacte en què han ocorregut; els columnistes a vegades opten per transgredir aquesta dicotomia de contextos enunciatius (producció/recepció) amb la finalitat d'apropar ambdós coordenades enunciatives. Amb aquesta estratègia poden escenificar una proximitat comunicativa que serà compartida per autor i destinatari gràcies a l'ús de determinades formes díctiques (especialment temps de present que aporten immediatesa). Açò és possible perquè la informació espaciotemporal, normalment, no és un tret informativament cabdal en les columnes $\mathrm{i}$, altrament, la ja comentada implicació autor-destinatari guanya actualització i vivacitat (Mancera, 2009: 68-72).

Al capdavall, tot sovint les pautes genèriques de la columna permeten utilitzar elements lingüístics (per exemple amb els díctics) tradicionalment relacionats amb l'oralitat a fi d'establir un marc d'interacció comunicativa molt més directa amb el destinatari.

Tanmateix, hem de remarcar que en manta volta algunes d'aquestes categories deixen d'assenyalar el context d'enunciació per referir-se, de manera endofòrica, al propi text (cotext). Així ocorre en els casos de dixi textual en què una forma díctica («aqueixa idea» o "després descriurem») remet a l'espai textual de forma que aquesta estratègia cohesiona el text alhora que reprèn el contingut semàntic d'una clàusula anterior.

Fet i fet, un vessant força interessant quan parlem de la dixi és aquella funció que fa referència a les persones de l'enunciació amb alguna d'aquestes marques lingüístiques: pronoms personals, morfemes verbals $i$ possessius de primera i segona persones. En canvi, la tercera persona se sol anomenar no-persona atès que no participa en presència en l'intercanvi comunicatiu. D'ací que l'aparició en els textos de pronoms de tercera persona tinga una funció anafòrica i no díctica. Tot i que per a J. M. Castellà «el pronom ell té la possibilitat del doble ús, díctic o tercera persona del discurs en situació, i la no-persona del discurs narrat» (Castellà, 1992: 188). 
Més enllà d'aquest matís d'enriquidora divergència, el més interessant és veure quines diferents funcions desenvolupen la primera i la segona persona ampliades i la segona del singular (Maingueneau i Salvador, 1995:15). Per una banda, el nosaltres pot fer esment a un ventall ampli d'opcions:

Jo $+0 \rightarrow$ nosaltres retòric, l'anomenat majestàtic com el de modèstia habitual dels texts científics amb voluntat d'amagar l'emissor i generar objectivitat.

Jo + tu (+tu...) $\rightarrow$ anomenat inclusiu ja que pretén implicar el destinatari en el discurs de manera que genera una consciència col-lectiva. Habitual de texts argumentatius.

$\mathrm{Jo}+$ ell $(+$ ell...) $\rightarrow$ anomenat exclusiu ja que deixa fora el receptor mentre compta amb terceres persones que l'emissor considera solidàries amb el seu missatge.

$\mathrm{Jo}+\mathrm{tu}+\mathrm{ell}+\ldots \rightarrow$ anomenat global ja que implica terceres persones amb un abast ampli.

Jo + tota la comunitat $\rightarrow$ anomenat universal ja que encabeix una globalitat extensa.

Una operació semblant podem efectuar amb la segona persona ampliada:

$\mathrm{Tu}+\mathrm{tu}+\mathrm{tu} \rightarrow$ fa referència al grup de receptors mentre el jo s'hi queda fora.

$\mathrm{Tu}+$ ell $\rightarrow$ remet al receptor i a una tercera persona.

$\mathrm{Tu}+$ ell + ell + ell $+\ldots \rightarrow$ designa un grup més extens en què no es troba l'emissor.

Pel que fa a l'ús de la segona persona del singular cal dir que determinades expressions dins de les columnes poden aparèixer com una mena de desdoblament del jo discursiu. En efecte, la columna, com dèiem en parlar de l'evolució del periodisme, abeura de l'assaig que té el costum de practicar la reflexió autodeliberativa i, consegüentment, presentar les deliberacions internes del jo com si foren un diàleg amb l'espill. Com veurem més avall, determinades preguntes que es fa l'autor funcionen en aquest sentit d'autoqüestionar-se quelcom en veu alta.

Més encara, l'ús del tu també té una finalitat impersonal quan s'empra sense referir-se a cap persona concreta sinó a qualsevol i a ningú. Amb aquest ús es buida semànticament el morfema de segona persona. Per exemple, en expressions com «hui en dia tu vas al banc i no saps si et donaran els diners... i això que són teus.» 
En relació a l'apel-lació al tu, volem comentar breument determinats valors d'algunes construccions interrogatives. Com sabem no tota estructura interrogativa té per objectiu fer una pregunta i resoldre un dubte ja que pot haver-hi un clivell entre el modus i l'element formal que es manifesta en l'enunciat. De fet, els actes de parla indirectes tracten aquests desequilibris entre la literalitat i la intencionalitat. Les interrogatives són un bon mener per a exemplificar aquestes situacions com es pot comprovar en oracions tan habituals com «Pots escudellarme?», quan és obvi que el parlant usa una interrogativa per a fer una petició i no per a resoldre cap dubte (altres preguntes prenen valors d'oferiment, suggerència, manament...).

En el cas dels texts de caire assagístic, els valors de les interrogatives també són diversos per la qual cosa cal que optem per una perspectiva pragmàtica per significar correctament aquests enunciats. Fent una selecció d'algunes de les possibilitats que activen les interrogatives en texts argumentatius com són les columnes podem trobar:

Preguntes autodeliberatives $\rightarrow$ (preguntes internes del subjecte assagístic que expliciten les seues reflexiones internes) $\rightarrow$ Cal intentar apagar tots els incendis?

Preguntes emfàtiques/retòriques $\rightarrow$ formulades sobre creences que se suposen compartides, apropa les interrogatives a les exclamatives. La diferència rau en el fet que les exclamatives es fonamenten en un coneixement factual compartit mentre que aquestes en una creença compartida $\rightarrow$ Hi ha un dolor més intens que perdre un fill?

Interrogativa orientada $\rightarrow$ la intenció de l'emissor rau en el fet que el destinatari confirme i compartesca la seua suposició $\rightarrow$ No creus que Felip ha jugat brut amb nosaltres?

Al capdavall, aquestes interrogatives són ben profitoses vist que empren una estratègia de cortesia com és la realització d'una pregunta per dissimular una orientació o una imposició argumentativa. Si una afirmació es presenta, no com una asseveració, sinó com una estructura oberta, el risc de transgressió social queda amortit.

Pel que fa a la dixi social hem de dir que, més enllà d'interpretar l'ús del vostè com a fórmula de respecte social, el factor que assenyala la tria entre el tu i el vosté rau en la "pertinència o no a la mateixa esfera de reciprocitat» (Maingueneau i Salvador, 1995: 20). Per tant, el tuteig recíproc indica una dimensió de proximitat i de solidaritat mentre que, en determinades situacions discursives, l'ús del vostè té la funció de refusar l'intent de proximitat que l'interlocutor volia establir. Des d'aquesta proposta "dir tu o vostè a algú, no és tant obeir un codi preestablert com acomplir un acte que té la propietat d'imposar al diàleg amb altri un cert marc» (1995: 20). 


\section{c) Connexió}

Un mecanisme cohesiu fonamental dins de la tipologia argumentativa és la connexió, ja que fa veure la relació sintàctica, semàntica i/o pragmàtica entre dos (o més) constituents de l'oració o del text i un connector. Per consegüent, s'estableixen dos tipus de connexió: l'oracional i la textual.

Si bé els connectors prototípics són les conjuncions, els connectors tenen una naturalesa categorial variada ja que hi trobem paraules i locucions denominades pels lingüistes de formes diferents (enllaços extraoracionals, adverbis conjuntius, locucions conjuntives...). Alguns autors (Conca i altres, 1998: 174-175) denominen aquest grup heterogeni de partícules connectives matisadors atès que poden aparèixer amb una conjunció precisant-ne o matisant-ne el significat. Per aquesta possibilitat combinatòria els consideren nexes secundaris; a més poden canviar la seua posició oracional $\mathrm{i}$ tenen caràcter parentètic. Tot i que no és aquest l'espai per a entrar en disquisicions terminològiques de les quals els connectors han estat protagonistes, M. J. Cuenca apunta que el terme matisador presenta el problema de suggerir una funció semàntica amb què precisa el significat de la conjunció amb què es combina i aquesta restricció terminològica fa que siga més pertinent el terme connector parentètic ja que "resulta més neutre i potser menys ambigu que matisador» (Cuenca, 2006: 75).

A diferència de la connexió oracional, la textual no genera cap tipus de relació sintàctica estructural, sinó que mostra la relació semàntica i/o pragmàtica entre els constituents units. Des d'aquesta perspectiva el connector és un senyal sintàctic que té la funció de palesar les relacions semàntiques $\mathrm{i}$ pragmàtiques que existeixen entre els constituents connectats.

Per tant, actuen en dos dimensions: des de la dimensió de la producció ajuden a construir la coherència del text i des de la dimensió de la recepció ajuden a la interpretació de sentit. Així, el connector manifesta una relació ja existent $\mathrm{i}$ ajuda el receptor a inferir-la amb la seua presència (Castellà, 1992: 170). De forma semblant, «la perspectiva de la teoria de la rellevància i la de l'argumentació són molt properes: es basen en la idea que els connectors es vinculen a instruccions discursives" (Cuenca, 2006: 33).

Malgrat que explicita la dificultat que suposa establir els significats que poden mostrar els connectors, aquesta autora en fa una proposta a partir de quatre relacions semàntiques bàsiques:

- Addició: continuïtat, intensificació, distribució, digressió, generalització, especificació, ampliació, equiparació.

- Disjunció: reformulació, exemplificació, resum. 
- Contrast: oposició, concessió, restricció, refutació, contraposició.

- Conseqüència: conseqüència (lògica o discursiva), conclusió.

Per a Ducrot i Anscrombe els marcadors argumentatius són aquells elements lingüístics que serveixen per senyalar estructuralment l'orientació argumentativa d'un enunciat. A partir d'aquesta definició, distingeixen entre els connectors argumentatius o elements que lliguen dos o més enunciats i els operadors argumentatius que afecten a un únic enunciat $\mathrm{i}$ hi actuen des de dins.

Pel que fa als operadors, direm que el ventall de possibilitats d'usar un determinat enunciat com a argument queda modificat -restringit- per l'addició de l'operador argumentatiu. En aquest sentit actuen diferents tipus de partícules com ara el com de l'exemple o altres de tipus escalar com almenys, fins i tot, sols, també...":

Com no m'abelleix seguir estudiant (argument), vaig a fer un tomb (conclusió).

Un altre vessant d'anàlisi de la connexió és el vinculat a les implicatures que emanen dels connectors. Per una banda, hi ha les implicatures convencionals, que deriven directament del significat de les paraules com és el cas del connector de contrast però i, per una altra, hi ha les implicatures no convencionals, que es generen per la intervenció interposada d'altres principis com el principi de cooperació o alguna de les màximes conversacionals (no convencionals conversacionals).

En el nostre treball hem analitzat els diferents valors de la copulativa $i$ en algunes columnes amb la finalitat d'exemplificar diversos contextos on aquesta conjunció no vehicula un valor copulatiu sinó consecutiu, temporal o contrastiu. Per exemple:

Les dones brillants busquen homes de nivell, $i$ els homes brillants "escullen companyes que s'assemblin a les mares" i perdin la xaveta pel seu èxit i la seva brillantina cerebral.

Observem que la primera $i$ té un valor de contrast mentre que la segona expressa un valor de causalitat. En canvi, la darrera té l'ús copulatiu que se li atribueix habitualment.

A més dels tipus de connexió -i de les diferents perspectives- que hem vist fins ara, podem identificar elements de connexió amb funcions pragmàtiques típicament vinculats a contextos d'oralitat. Hem de pensar que -ja ho hem dit en aquest paper- els mass media reflecteixen ostensiblement una clara transversalitat entre els modes oral i escrit, tot palesant més bé una complementarietat que una oposició entre les estratègies discursives d'ambdós modes. 
Així, els connectors pragmàtics:

Són elements parentètics, amb posició generalment inicial, que marquen unió o transició dins de la conversa i tenen un valor modalitzador. Es tracta $d$ 'interjeccions o d'elements intermedis entre interjeccions i connectors parentètics, sovint amb un grau de gramaticalització poc elevat, que, pel fet que pressuposen la presència contigua d'una oració, es pot dir que funcionen com a connectors textuals (Cuenca, 2006: 168).

Maingueneau i Salvador opten pel terme marcador discursiu per referirse als elements que manifesten la connexió entre diferents constituents del text i que «remeten al procés d'interacció discursiva que se serveix del text com a instrument» (1995: 185). Així doncs, els marcadors guien el lector en el procés interpretatiu gràcies a senyalitzar una determinada organització textual i, de més a més, manifesten una actitud modalitzadora entre l'autor i els continguts exposats.

Com a gènere de caire autodeliberatiu, la columna aprofita aquests recursos, com ara els marcadors de contrast, per exposar l'oposició entre arguments i contraarguments. Tanmateix, si una opció rau a emprar els connectors lògics d'oposició, concessió, conseqüència... una altra malda per emprar elements habituals de l'ús col-loquial amb aquestes funcions pragmàtiques. Certament, podem trobar usos de l'adverbi bé (representatiu oral d'expressió d'acord) fent funcions de marcador de contrast argumentatiu:

«L'únic ideal respectable és la sacietat. Bé: totes les sacietats sumades.» (Sagitari)

Amb aquesta estratègia l'enunciador aconsegueix donar una imatge de cortesia dialogant alhora que no s'està de dir la seua de manera subtil.

Per una altra banda, aqueix caràcter modalitzador dels marcadors es posa de manifest en l'ús de determinades interjeccions. L'autor construeix una mena d'escenografia retòrica en què manifesta la seua emotivitat respecte a allò enunciat. $\mathrm{Hi}$ ha en aquest recurs un joc de complicitats amb el lector, que haurà d'interpretar el sentit de protesta, indignació, sorpresa... de l'enunciador (Maingueneau i Salvador, 1995: 187-188):

«De fet, els morabits, els rabins i els cardenals són una mateixa fauna.

UF?..." (Notes d'un desficiós)

Per tant, a més dels tipus de connexió - i de les diferents perspectivesque hem vist fins ara, podem identificar elements de connexió amb funcions pragmàtiques típicament vinculats a contexts d'oralitat. Hem de pensar que -ja ho hem dit en aquest paper- els mass media reflecteixen ostensiblement un clar contínuum entre els modes oral i escrit, tot palesant més bé una complementarietat que una oposició entre les estratègies discursives d'ambdós modes. Fet i fet, l'operació que han de 
mamprendre emissor i destinatari és interpretar, respectivament i a partir de les seues competències comunicatives, els valors funcionals d'aquests elements atenent al contracte comunicatiu que proposa la columna com a gènere.

\section{Proposta de comentari}

La intel-ligent no es casa

Si ho han fet les universitat d'Edimburg, Aberdeen, Bristol i Glasgow i ho ha publicat The Sunday Times, se li ha de donar crèdit. Aquestes són les conclusions de l'estudi fet durant 40 anys: com més avança el nivell intel-lectual de la dona, més baixa la seva possibilitat matrimonial, fins al punt que les més llestes tenen un $40 \%$ menys d'opcions. Paral-lelament, per cada augment de 16 punts de coeficient, els homes augmenten un $35 \%$ de possibilitats de casar-se. No només això, les dones brillants busquen homes de nivell, i els homes brillants "escullen companyes que s'assemblin a les mares" i perdin la xaveta pel seu èxit i la seva brillantina cerebral. És a dir, la dona accepta la competència intel-lectual en la convivència, i l'home no la suporta. Remata una altra anàlisi a I'Australian Twins Registry: "Les intel-ligents odien perdre el temps, i per això no el perden amb els tontos". Amb la qual cosa, troben menys opcions.

Un simple estudi que em recorda aquella expressió explícita que va encapçalar el capítol d'un llibre meu: "El poder femení arruga el penis". L'ha arrugat durant dècades, fins al punt que la intel-ligència masculina era considerada un atractiu, i la femenina, una impertinència. ¿̇lnseguretat masculina? Sens dubte. No obstant això, i malgrat l'estudi, crec que cada dia hi ha més homes seduïts per l'èxit femení i la seva libido no només no s'espanta, sinó que s'engrandeix. Avui hi ha homes que estimen dones brillants. Són els més interessants: saben ser homes sense necessitat de competir com a mascles.

Pilar Rahola, El Periódico, 6 de febrer de 2005

Aquesta columna fou publicada per El Periódico el 6 de febrer de 2005. L'autora, Pilar Rahola, ha col·laborat durant els últims anys en nombrosos mitjans de comunicació com a columnista de premsa escrita o bé com a participant habitual en diferents gèneres audiovisuals de diverses cadenes de ràdio i televisió. A causa dels seus posicionaments periodístics ha estat guardonada per lluitar contra l'antisemitisme i per denunciar les discriminacions cap a les dones.

\section{Estructura:}

1r paràgraf: Presentació del tema i arguments antiorientats

Tesi antiorientada

Reformulació de la tesi anterior

2n paràgraf: Ampliació dels arguments

Tesi definitiva

Conclusió valorativa 
El text s'articula a partir de dos eixos discursius que corresponen, respectivament, a cadascun dels dos paràgrafs de què consta la columna. El primer paràgraf presenta el tema, els arguments d'autoritat i la tesi antiorientats, tot informant des d'una perspectiva objectiva d'un estudi amb què s'analitzen les possibilitats de trobar parella (tema). En canvi, el segon paràgraf es caracteritza per una presència destacada de la primera persona de l'autora, que rebat la tesi anterior alhora que hi manifesta la seua posició. Tot i que l'autora havia acceptat l'orientació global de l'anàlisi de l'estudi, hi ha una variable que resulta fonamental per entendre el seu canvi de parer: el pas del temps està produint una evolució en un sector dels homes pel que fa a acceptar, com a parella, dones amb un alt nivell intel-lectual. Fet aquest plantejament global, anem a pams per treure l'entrellat dels elements més destacats del text.

Per bé que el títol n'avança el contingut, ho fa d'una manera esbiaixada que té com a finalitat atraure l'atenció del lector més que servir de títol objectivament temàtic. A més, aquesta pretesa ambigüitat es fa més evident amb la primera oració del text, que inclou dos pronoms catafòrics que generen una expectativa de lectura ja que ens remeten a algun element posterior del text que només coneixerem si continuem llegint:

Si ho han fet les universitats d'Edimburg, Aberdeen, Bristol i Glasgow i ho ha publicat The Sunday Times, se li ha de donar crèdit.

Aquesta condicional, amb una apòdosi impersonal, serveix per presentar objectivament les conclusions de l'estudi (tema) a les quals feien referència els pronoms catafòrics anteriors i que són els arguments que fan costat a la tesi antiorientada. Ras i curt: pel que fa a les dones, un alt nivell intel-lectual és inversament proporcional a les possibilitats de casarse. Pel que fa als homes, ocorre a l'inrevés: com més intel-ligents, més probabilitats matrimonials.

Com dèiem suara, Rahola presenta aquesta tesi no com a pròpia, sinó amb l'auctoritas de les prestigioses universitats responsables de l'estudi i del mitjà de comunicació que n'ha publicat els resultats. De fet, aquesta objectivitat es fa més palesa amb les dades exactes de les conclusions i, això sí, amb un operador escalar d'informativitat (fins al punt) que augmenta el potencial argumentatiu del contingut:

Com més avança el nivell intel·lectual de la dona, més baixa la seva possibilitat de casar-se, fins al punt que les més llestes tenen un $40 \%$ menys d'opcions, per cada augment de 16 punts de coeficient els homes augmenten un 35\% de possibilitats de casar-se.

A més a més, el prestigi de l'esmentat estudi es consolida amb una informació sobre el període de temps durant el qual s'ha desenvolupat: ni més ni menys que 40 anys. Tanmateix, recordarem aquesta darrera dada per reflexionar-hi més avall. 
Un marcador discursiu d'intensificació amb dixi textual (No només això) afig èmfasi amb més explicacions que resumeixen les conclusions de l'estudi. Tanmateix, en aquesta ocasió l'autora barreja dues opcions estilístiques oposades. Per un costat, busca l'objectivitat reportant en estil directe amb signes tipogràfics una part de la informació i, per un altre, en sintetitza una part amb uns termes modalitzats per pertànyer a un registre més col-loquial, que reforça la proximitat amb el lector (perdre la xaveta); o bé per traslladar una ironia quan fa un joc de paraules amb els conceptes brillant com a talentós i brillantina com a cosmètic per a fixar la lluentor dels cabells:

Els homes brillants "escullen companyes que s'assemblin a les mares", i perdin la xaveta pel seu èxit i la seva brillantina cerebral.

Tot seguit, un connector textual de reformulació inclou una deducció que serveix de tesi d'allò dit fins ara. Fixem-nos que, en aquesta ocasió, l'autora també s'amaga amb una tercera persona però la tria eufòrica d'un verb que indica tolerància (accepta) per a descriure la conducta de les dones contrasta amb la construcció negativa disfòrica (no suporta) per a descriure el comportament irritable del homes:

És a dir, la dona accepta la competència intel/lectual en la convivència, $i$ I'home no la suporta.

Per una altra banda, no volem deixar passar l'ocasió per fer un comentari sobre els valors de les conjuncions $i$ en aquest fragment. En alguns casos la conjunció $i$ té el valor copulatiu que se li sol concedir habitualment; no obstant, en l'exemple anterior copsem com pren un valor de contrast de caire argumentatiu. Observem uns altres exemples d'aquesta diversitat d'usos:

Les dones brillants busquen homes de nivell, i els homes brillants "escullen companyes que s'assemblin a les mares" i perdin la xaveta pel seu èxit i la seva brillantina cerebral.

Fet i fet, aquesta primera $i$ té un valor de contrast semblant al de l'exemple anterior mentre que la segona expressa un valor consecutiu. Per últim, la darrera $i$ enllaça com a copulativa dos sintagmes nominals. Per tant, aquest exemple pot ser ben útil per proposar com els valors de $i$ es basen en la idea que la implicatura que dóna lloc a aquesta conjunció és conversacional generalitzada, és a dir, no es tracta de continguts codificats convencionalment, sinó implicats conversacionalment.

Si tornem al final d'aquesta part del text, que coincideix amb el primer paràgraf, cal comentar que hi recull un altre argument d'autoritat en estil directe malgrat que un verb de dicció ben modalitzat (remata) intensifica aquesta altra deducció argumental, que sintetitza bona part de tot el que $s^{\prime}$ ha exposat fins ara. El contrast lèxic per al-ludir respectivament a les dones preparades $\mathrm{i}$ als homes poc formats és obvi: 
Remata una altra anàlisi a l'Australian Twins Registry: "Les intel.ligents odien perdre el temps, i per això no el perden amb els tontos".

Dèiem en encetar aquest paper que hi havia diferències considerables entre el primer paràgraf $i$ els segon pel que feia a la línia discursiva seleccionada en cadascun d'ells. Ara és el moment de parlar-ne atès que ja topem amb aquest gir en la primera oració:

Un simple estudi que em recorda aquella expressió explícita que va encapçalar el capítol d'un llibre meu: "El poder femení arruga el penis".

En primer lloc, cal dir que l'adjectiu axiològic "simple" suposa un canvi de perspectiva evident respecte a la valoració que Rahola havia fet de l'estudi de les universitats anglosaxones: el prestigi anterior s'ha esvaït amb la tria d'un únic adjectiu. En segon lloc, l'autora s'incorpora, de manera explícita, al text amb uns díctics de primera persona i amb una autocitació amb què ridiculitzar les pors freudianes de l'home quan se les ha de veure amb una dona amb poder intel·lectual.

Si bé aquest començ de paràgraf -i la idea posterior com ara veuremsemblen actuar d'arguments que reforcen la línia argumental exposada fins ara, copsem que alguns elements insinuen uns matisos de reformulació de la tesi anterior:

L'ha arrugat durant dècades, fins al punt que la intel-ligència masculina era considerada un atractiu, i la femenina, una impertinència.

En concret, ens centrem en els díctics que es refereixen al passat i a d'altres expressions que també al-ludeixen a temps pretèrits (durant dècades): aquella expressió, va encapçalar i era considerada.

Per tant, aquest "simple estudi" no ha aconseguit aportar res de nou perquè Pilar Rahola ja sabia -i escrivia- des de feia temps sobre aquesta doxa masclista que en l'expressió de l'autora agafa més volada gràcies a un operador escalar d'informativitat (fins al punt) i a una conjunció "i" amb valor de contrast argumentatiu (... i la femenina una impertinència).

Després l'autora afig una expressió diafònica que incorpora al text la suposada veu d'aquells lectors que no capeixen que aquesta conducta masculina amaga profundes vacil.lacions. Amb aquesta finalitat activa diafònicament aquesta interrogació d'incredulitat (¿inseguretat masculina?). No obstant açò, cal tindre present que el gènere columna abeura de les condicions autodeliberatives de l'assaig i aquest tret provoca que aquest tipus de preguntes de caire diafònic s'entenguen com a manifestacions dels propis dubtes de l'autor, que, de retruc, són transsumpte dels interrogants del propi lector. Després d'aquest qüestionament, contesta a la pregunta de manera categòrica per refermar-hi la seua postura: Sens dubte. 
Tanmateix, acabem de dir que els elements temporals que feien referència al passat deixaven una primera petjada d'un tomb en l'argumentació. Vet ací que dos connectors concessius expliciten aquest canvi d'orientació argumentativa que recolza, a partir d'un verb epistèmic de dubte en primera persona, en un més estable i modern posicionament d'un sector dels homes. Si la defensa de la primera tesi antiorientada se sustentava en variables referides al passat $i$ a un estudi fet durant 40 anys, la nova tesi se sustenta en la creença que ara els temps i els costums -com diu el tòpic- estan canviant. Per aquesta raó, aquest darrer fragment posa de relleu verbs $\mathrm{i}$ expressions temporals de present:

No obstant això, i malgrat l'estudi, crec que cada dia hi ha més homes seduïts per l'èxit femení i la seva libido no només no s'espanta, sinó que s'engrandeix. Avui hi ha homes que estimen dones brillants.

També convé destacar, per una banda, la tria de mots eufòrics per referirse a aquest modern sector masculí (seduïts $i$ estimen) mentre que els termes escollits per defensar la tesi antiorientada no incloïen trets lligats a la sensibilitat, sinó al contracte matrimonial (possibilitat matrimonial, casar-se) o a l'elecció freda d'un perfil maternal (escullen companyes que s'assemblin a les mares). A més a més, l'autora segueix amb la sinècdoque sexual per, amb una construcció adversativa reforçada amb un operador escalar, assenyalar que la virilitat ja no s'arruga sinó que augmenta quan I'home supera les inseguretats envers les dones brillants.

Finalment, tanca el text amb una conclusió segons la qual valora positivament aquest actual model de masculinitat que ha après a conviure d'igual a igual amb les dones, tot oblidant conductes purament biològiques. Al capdavall, aquesta idea final de l'autora encoratja els lectors masculins perquè opten per aquest camí en la seua relació amb les dones:

Són els més interessants: saben ser homes sense necessitat de competir com a mascles.

Al remat, aquesta columna pot ser de profit per a analitzar com, dins d'un únic text, poden haver-hi dues parts - i ací paràgrafs- ben diferenciades pel que fa a les opcions lingüístiques triades i, consegüentment, als objectius que s'hi cerquen. Ens referim, per una banda, a la intenció de cercar una línia d'objectivitat en la primera part del text i, per una altra, al capgirament de la segona part en què la presència del jo de l'autora és fa més evident.

En particular, podríem comentar la significació pragmàtica d'alguns elements concrets:

- Els elements inicials catafòrics per fer créixer l'interès per la lectura. 
- Els elements lèxics que modalitzen l'exposició dels arguments objectius i la tria de mots eufòrics i disfòrics que assenyalen una determinada orientació argumentativa.

- Els valors no copulatius de la conjunció $i$.

- La funció de les referències temporals.

\section{Conclusió}

Amb la presentació d'aquest article, hem intentat justificar les potencialitats didàctiques que la columna proporciona gràcies al seu caràcter híbrid i a una essencial brevetat que s'adapta perfectament a les millors variables d'un comentari de text: la possibilitat de realitzar una lectura intensiva, analítica, crítica $\mathrm{i}$, en determinades ocasions, autònoma respecte a la resta de textos que l'envolten. Escollit el gènere a partir del qual desenvolupar les anàlisis, hem aplicat les aportacions de la pragmaestilística com a mètode de comentari.

Certament, pensem que les potencialitats de la pragmaestilística permeten una interpretació més arrodonida dels textos pel fet d'eixamplar l'anàlisi, per una banda, envers determinats components discursius en un àmbit que depassa el marc oracional $i$, per una altra, envers els efectes pragmàtics $i$, particularment, argumentatius que vehiculen algunes tries estilístiques.

Coordinadament amb aquesta línia d'anàlisi, hem segmentat amb l'escalpel components lingüístics específics que senyalaven, més o menys explícitament, les dreceres argumentatives de les columnes comentades. Com dèiem suara, la identificació i l'assimilació comprensiva d'aquestes tries lingüístiques ajudarà a aquest fi per tal que l'alumne entenga les intencions comunicatives dels discursos que ens envolten.

Comptat i debatut, durant aquest treball hem intentat demostrar per què el gènere columna conté unes potencialitats educatives ben aprofitables gràcies a les seues característiques com a text breu, d'elaboració culta i integrador d'elements estilístics ben diversos. A més, el comentari presentat ens ha fet veure com la metodologia emprada ha resultat adequada a fi de donar sentit als textos, tot superant línies de treball basades exclusivament en la identificació mecànica d'elements lingüístics. 


\section{Bibliografia}

CASTEllà, J. M. (1991). De la frase al text. Teories de l'ús lingüístic. Barcelona: Empúries.

Charaudeau, P. I Maingueneau, D. (2005). Diccionario de anàlisis del discurso. Buenos Aires: Amorrortu.

CONCA, M. i altres (1998). Text i gramàtica. Teoria i pràctica de la competència discursiva. Barcelona: Teide.

CUENCA, M. J. (1996). Comentari de texts. Picanya: Edicions del Bullent.

CUENCA, M. J. (2006). La connexió i els connectors. Barcelona: Eumo.

GOMIS, L. (1989). Teoria dels gèneres periodístics. Barcelona: Edicions 62.

ESCANDELL, M. V. (1996). Introducción a la pragmàtica. Barcelona: Ariel.

LÓPEZ PAN, F. (2008). "La columna como paradigma de los géneros periodísticos de autor" en Gómez Calderón (ed.): El artículo literario: Manuel Alcàntara. Málaga: Universidad de Málaga, 55-68.

MAINGUENEAU, D. I SALVADOR, v. (1995). Elements de lingüística per al discurs literari. València: Tàndem.

MANCERA, A. (2009). "Oralización" de la prensa española: la columna periodística. Berna: Peter Lang.

SAlvadoR, V. (2003). "Pragmàtica i estilística". Noves SL, Revista de sociolingüistica, 4 [http://www6.gencat.net/llengcat/noves], 1-7.

SALVADOR, V. (2011). "Lectura analítica i ensenyament: el comentari de textos literaris" dins d'Anna Camps et al.:Llengua catalana i literatura. Complements de formació disciplinària, 11 vol 1. 117-141. 